\title{
HEALTH NEEDS OF THE PEOPLE OF PREK TORL - CAMBODIA: A CROSS SECTIONAL STUDY
}

\author{
Mitra Andini Sigilipoe ${ }^{1}$, Katrin Tsang ${ }^{2}$ \\ ${ }^{1}$ Medical Faculty of Duta Wacana Christian University \\ ${ }^{2}$ School Of Public Health and Primary Care Chinese University of Hong Kong
}

Correspondence: mitra.sigilipoe@gmail.com

\begin{abstract}
S
Background: Several studies have mentioned about health problems of people who lives within a landfill area, especially for pregnant mothers and the health outcomes such as low birth weight, spontaneous abortion, infant mortality, and other health issues. In Prek Torl-Pnomh Penh-Cambodia, about 200 households, who are living under poverty line, dwell in a slum surrounded by heaps of decaying wastes. These households consist of women within productive age of 18-49 years old, and they are exposed to the hazard of wastes every single day.

Objectives: The study is aimed to assess the need of Prek Toul's population, especially health problems regarding maternal and child health.

Methods: Household surveys were carried out in June 2012 and 2013. In 3 days, a team from S.H. Ho College, under supervision of Prof. Katrina Tsang, conducted the survey to 88 and 90 households, respectfully. Data was analyzed using frequency and compared with Cambodia's 2010 Demographic and Household survey result. Statistical tests were also used to see if there was any correlation or association between household income, education level or status, antenatal service, and infant mortality.

Conclusion: The findings of this study suggested that low level of education and income is connected with the uptake of antenatal service. The perception of access to health care is not in line with the uptake of antenatal service. More qualitative studies might be needed to explore the reason for that issue. Further studies may shed more light on the reason of why women did not use antenatal service, and in time may help in designing new interventions for delivering more suitable maternal and child health care for the particular population.
\end{abstract}




\title{
MASALAH KESEHATAN DI MASYARAKAT PNOMPHEN - KAMBOJA: METODE POTONG LINTANG
}

\author{
Mitra Andini Sigilipoe ${ }^{1}$, Katrin Tsang ${ }^{2}$ \\ ${ }^{1}$ Fakultas Kedokteran Universitas Kristen Duta Wacana \\ ${ }^{2}$ School Of Public Health and Primary Care Chinese University of Hong Kong
}

Korespodensi: mitra.sigilipoe@gmail.com

\begin{abstract}
ABSTRAK
Latar Belakang: Beberapa penelitian sebelumnya telah menyatakan adanya masalah kesehatan di populasi masyarakat yang hidup di dalam atau sekitar Tempat Pembuangan Akhir (TPA). Masalah kesehatan yang timbul terutama berkaitan dengan kesehatan ibu dan anak, seperti Berat Badan Lahir Rendah (BBLR), abortus spontan, angka mortalitas neonatus, serta masalah kesehatan lainnya. Di suatu daerah yang bernama Prek Torl, di Pnomh Penh-Kamboja, terdapat suatu populasi yang tinggal di area TPA. Populasi ini terdiri dari kurang lebih 200 keluarga, dengan tingkat ekonomi di bawah garis kemiskinan. Di dalam populasi ini terdapat sejumlah perempuan usia produktif (18-49 tahun) yang tinggal berdekatan dengan tumpukan sampah dan terpapar oleh zat-zat berbahaya dari tumpukan sampah tersebut.

Tujuan dan Manfaat: Penelitian ini bertujuan untuk memetakan masalah kesehatan yang ada di populasi Prek Torl, terutama yang berkaitan dengan kesehatan ibu dan anak.

Metode: Pada tahun 2012 dan 2013, Survey Kesehatan Rumah Tangga dilaksanakan di Prek Torl oleh satu tim dari S.H. Ho College, di bawah supervisi Prof. Katrina Tsang. Survey dilaksanakan dalam 3 hari, di bulan Juni 2012 dan 2013. Sebanyak 88 dan 90 Kepala Keluarga (KK) berpartisipasi dalam survey ini, dan mereka terpilih melalui metode convenience sampling. Data yang terkumpul dibandingkan frekuensinya dengan data dari Survey Demografis dan Kependudukan Kamboja 2010. Analisa bivariat juga dilakukan untuk mencari korelasi antara tingkat pendidikan atau pendapatan dengan pemanfaatan pemeriksaan kehamilan (antenatal care $=\mathrm{ANC}$ ), angka mortalitas neonatus $/<1$ tahun $/<5$ tahun.

Kesimpulan: Penelitian ini menemukan adanya korelasi antara tingkat pendidikan dan pendapatan dengan tingkat pemanfaatan ANC. Persepsi terhadap akses pelayanan kesehatan tidak sesuai dengan pemanfaatan ANC. Penelitian lebih lanjut, terutama dengan metode kualitatif, diperlukan untuk mengeksplorasi alasan kurangnya pemanfaatan ANC di populasi ini, dengan harapan hasil dari penelitian ini dan berikutnya dapat berkontribusi dalam penyusunan program kesehatan ibu dan anak yang bermanfaat untuk populasi Prek Torl.
\end{abstract}




\section{BACKGROUND}

\section{Landfill's Life}

Previous researches showed that living in or near landfill area have been correlated with several health problems such as low birth weight, birth defects, infant mortality, respiratory problems or even cancers. ${ }^{1}$ For populations that reside within range of 2 kilometers of a landfill, there was limited evidence of increasing risks for congenital anomalies and low birth weight, and more increasing risks if the landfills were dealing with toxic wastes. ${ }^{2}$ The limit of these evidences is due to the wide range of pollutants, different pathways of exposure for each pollutant, low-level of exposure within a period of time and possibility of interaction or synergism between pollutants. ${ }^{2}$ Therefore, each landfill may have different effect on health according the characteristics of the pollutants that is contained.

\section{Prek Torl - Cambodia}

Cambodia is still one of the poorest countries in Southeast Asia. Nearly 20.5\% of its 14.86 million population lives under the poverty line, despite their rapid GDP growth. That means around 2.8 millions of Cambodian are still living with less than US\$ 1.25 per day. ${ }^{3}$ Like many developing countries, the country has its own challenges in meeting its people needs, such as health issues. The main health issues related to poverty in Cambodia are malnutrition and access to health care. For delivering health care to their civilians, Cambodia is setting a mixed system of Minimum Package of Activity (MPA), which is provided by primary health care centers, and Complementary Package of Activity, which is provided by the referral hospitals. ${ }^{4,5}$ The MPA is consisted of immunization, family planning, antenatal care, nutritional supplementations, and simple curative care (diarrhea, acute respiratory infections, malaria and tuberculosis). Other than those primary care, more advance services such as surgery and so on, is provided by the CPA. ${ }^{5}$ The government of Cambodia, through its Ministry of Health, has provided 1,409 Public Health Centers, but only 43\% of the centers provide full MPA. The government challenges in providing adequate health care services usually are (1) absence of key personnel; (2) the inadequacy of essential drugs support; (3) the absence of other operational guideline requirements. ${ }^{4}$ The government has spent $21.27 \%$ of their national budget for manage the issue of health services deliveries, but the rest of the cost of those services is burdened on the civilians' own income. $73.1 \%$ of the health services cost are paid by civilians or by out-of-pocket funding, and 68\% out of those percentages are going to the private health care service providers. ${ }^{4}$ Considering the level of poverty in Cambodia, this condition lead to practices of borrowing money and selling any properties that a household has to cover the health services cost when they need it. ${ }^{5,6}$

One of the poorest populations in Cambodia is in Steung Meanchey. The district, or sangkat in Khmer language, is part of Phnom Penh province and the area was used a landfill for the waste from Phnom Penh city. The landfill was closed down in 2009 and stated as inactive. But the mountain of decaying trash is still sitting there, along with around 1000 households that live in the area. $^{7}$ A part of that inactive landfill is a village called Prek Torl, with approximately 200 families live in the area, with minimum housing, plus questionable water and sanitation system. These families consist of women of reproductive age and their children. It is quite concerning, since 
many of previous studies in other landfill areas have proved on certain degree that the pollutants from the wastes may have serious effects on maternal and child health. Such studies have not been done in this area, therefore this study will try to identify health problems in this community, such as maternal and children health problem.

\section{STUDY DESIGN}

\section{Method}

This is a cross sectional study, based on a household survey which was done 2012 and 2013, in Prek Torl village, by a team from S.H. Ho College and lead by Professor Katrina Tsang. Convenience sampling was used for the survey, and subjects were selected by the next birthday method for those over 18 years of age. 88 households participated in the 2012's survey, while 90 other households participated in the 2013's survey. The survey was delivered via face-toface interview, by trained interviewers from Hong Kong, accompanied by local Cambodian's interpreters, in order to aid language issues in delivering the surveys. The surveys were done by 4 teams, in about 4 days.

\section{Survey's Content}

In 2012, the questionnaire was divided into 6 main themes, such as background information (demographic data); general health or condition; reproductive health; child health and family planning; water, personal hygiene and sanitation; mental health. While in 2013, it was decided to focus more on maternal health, reproductive health, and personal hygiene plus sanitation. The survey has been approved by the Ethics Committee of the Chinese University of Hong Kong.

\section{Statistical Analysis}

Descriptive analysis, such as frequencies, was applied to all of the data, and comparable data is compared with the result of Cambodia's Demographic and Health Survey in 2010, to see if there was any discrepancy of frequencies between this particular area and national's. ${ }^{8}$ Demographic data such as education or literacy and household income were statistically tested against health outcome data such as uptake of antenatal care (ANC), number of visits of antenatal care, and infant mortality, to see if there was any correlation or association between variables. All data was recorded and calculated by SPSS.

\section{RESULT}

\section{Demographic Findings}

In 2012, 88 persons from 88 households participated in the survey, representing around 477 residents from all of those households. 19\% of the respondents were male and 81\% were female. Since the interview was conducted during daytime, we assumed that the female were present in the house more, because the men were out working or resting after a night shift. 73.9\% of the respondents were within 16-49 years old, which is within the range of productive age, while $26.1 \%$ were 50 years old or older. The mean age of households informants was 40.55, with the youngest was being 20 and the oldest was 83 years old. $86.4 \%$ of respondents were married, while $13.6 \%$ were being either single, widowed, or divorced. $47.7 \%$ of respondents were working as trash collector, collecting trash from the nearest inactive landfill of Steung Mean Chey, or from other landfills. 27\% of respondents were housewives, while only $4.5 \%$ stated that they were doing skilled labor. 41.4\% 
of respondents were making less than $20 \$$ per month, $32.2 \%$ were making more than 60\$ per month, while 26.4\% were making in between 20-59\$ per month. $65.5 \%$ the major source of the respondents income were from collecting trash and selling it, 9.2\% from wages, $8 \%$ from selling things, $9.2 \%$ stated from multiple source of income and $8.1 \%$ were from either agriculture, being a driver, being a beggar or receiving money from her children. $59.1 \%$ respondents stated that they were illiterate, or cannot read or write in Khmer (which is their national language), while $40.9 \%$ stated that they were literate. The mean value for education attainment years were 1.95, with the minimum 1 year and maximum 8 years or $8^{\text {th }}$ grade of secondary school.

In 2013, 90 household informants responded to the survey, representing about 480 residents in all participated households. The mean value for total residents is $7.12 .84 .3 \%$ of the household informants were female, while $14.6 \%$ were male. $68.9 \%$ of the respondents were within 18-49 years old, which is within the range of productive age, while $31.1 \%$ were 50 years old or older. $81.6 \%$ of respondents were married, 3.4\% were divorced or separated, 11.5 were widowed, and $3.4 \%$ were never married. $52.2 \%$ of respondents were working as trash collector, $12.2 \%$ of respondents were housewives, and $14.4 \%$ stated that they had other unspecified job; while $21.2 \%$ were either a clerk, skilled labor, unskilled labor, retired, unemployed, or unable to work. $12.2 \%$ of respondents were making less than 20\$ per month, $57.8 \%$ were making more than $60 \$$ per month, 23.3\% were making in between 20-59\$ per month, while 6.7\% were being either not having an income or not aware of the amount of their household income. 65.9\% of the major source for respondents' income was from collecting trash and selling it, 20\% from wages, 5.9\% from welfare, and $8.2 \%$ of respondents stated from other sources. These other sources were selling things, being construction worker, being fortune teller, driving motor taxi, washing clothes service, being a beggar or receiving money from her children. $62.3 \%$ of the respondents stated that they were illiterate, or cannot read or write in Khmer, while 36.4\% stated that they were literate, and 1.3\% was of unknown status. The mean value for education attainment years were 4.75 , which were within range of primary school education level.

\section{General Health}

From the 2012's survey, 4.5\% of respondents thought that their health were in bad condition, $26.1 \%$ in bad condition, $46.6 \%$ thought it was fair, $14.8 \%$ thought they were good, 3.4\% thought they were very good, while 4.5\% were not sure of their condition. $69 \%$ of respondents claimed that they had health problems within the past 12 months, $27.6 \%$ did not have, and $3.4 \%$ of respondents could not remember if they had any health problem in the past 12 months. Out of the 69\% who had health problems, $83.3 \%$ were seeking medication for their problems, $16.7 \%$ did not. Out of the $16.7 \%$ who did not seek medication, $88.1 \%$ could not specify a reason of why they weren't seeking medication, 6\% stated that the cost of health care is unaffordable and 2.4\% did not think they need to. This quite in contrast to the question barriers to seek medication, which was asked to all 88 respondents and gained 55 responses, where $41.8 \%$ stated that health care cost was unaffordable and $12.7 \%$ said to have multiple barriers. $39.3 \%$ of respondents visited NGO clinics to seek medication when needed, while 14.3\% went to the district hospital, $17.9 \%$ were 
seeking medication from multiple health care services, $7.1 \%$ visited health centre, 2.4\% would seek local pharmacy, and the rest 19\% were unspecified. $75.9 \%$ preferred to go to western doctor or nurse (western medicine), and only 9.2\% went to Khmer traditional healer. Trust for NGO's health care provider was 90.9\%, which is higher than the trust for local health care provider that is 83\%. 73.9\% of the responders thought it was easy for them to access health care service when they need to, while $21.6 \%$ thought it was not was not easy for them, and 4.5\% did not know. 30.2\% of respondents stated that they had an infectious disease in the last 12 months. Out of the 30.2\%, 57.7\% were diarrhea, $19.2 \%$ were having more than one type of infection, $7.7 \%$ were having Tuberculosis, and the rest 15.4\% were either a case of malaria or typhoid fever or food poisoning or scabies.

\section{Reproductive Health}

For 2012's survey, the knowledge of contraception of the respondents were assessed by some statements with simple "yes" or "no" answers ("don't know" and "decline to answer" were available as options as well). 70.9\% stated that they know that wearing condom can prevent pregnancy. $42.2 \%$ said that contraception has nothing to do with family planning, in contrast to 30.1 who said otherwise. 39\% thought that withdrawal method will prevent STI, while 26\% thought it will not. $54.7 \%$ did not think that more children will ensure more income in the future, while $27.9 \%$ thought it will. $75.6 \%$ expressed their interest in learning about contraception method, and $76.2 \%$ believe that having one and only sexual partner will help in preventing STI. $79.1 \%$ said that they will attend family planning's education program. $65.9 \%$ stated that they will use condom if they have STI. The mean value for the number of times that female respondents have given birth in their lifetime was 3.81, with minimum of $O$ and maximum 12 times. $40.7 \%$ of the female respondents stated that they had given child birth at public hospital or public clinics, while $30.2 \%$ were given at home, 9.3 at a health centre and $12.8 \%$ stated that they had used more than one type of health service centre to delivertheir babies. $26.4 \%$ of respondents stated that the baby deliveries were attended by doctors, $12.6 \%$ by nurses, $25.3 \%$ by midwives, and $11.5 \%$ by kru Khmer. $58.6 \%$ of women in the household claimed that they have received supplements during 6 weeks after giving birth, while $34.5 \%$ claimed they haven't. 25\% of respondents who received the supplements remembered that it was vitamin A, 22.7\% stated that it was iron tablets, and $10.2 \%$ stated that it was deworming medication. For question about ever miscarriage episode in the households, $29.9 \%$ of respondents claimed that they had a miscarriage or stillbirth, while $62.1 \%$ claimed that they had not. $13.6 \%$ of respondents said that they have had an abortion and $78.4 \%$ said that had not gone through any abortion.

For 2013' survey, from 90 households' informants, $88.9 \%$ stated that they had been pregnant. From those respondents, the mean value for the number of time they have been pregnant was 5.025, with minimum of 1 and maximum of 14 times. However, the mean value for the number of babies that they have given birth to was 4.18, with minimum of 1 and maximum of 10 babies. The mean value for intervals of years between two last pregnancies was 2.89, with a minimum of 0 year (less than 1 year) and a maximum of 19 years. During pregnancy, $62.4 \%$ of the women did visit a health professional (doctor) nurse/midwife) or taking antenatal care (ANC) before they gave birth, 36.3\% did not take any ANC, while 1.3\% did not 
know if she had take ANC or not. Out of those who did not take any ANC, 42.9\% thought they did not need it, $17.9 \%$ could not pay for the healthcare service, $7.1 \%$ could not pay for transport to go there, $7.1 \%$ did not know the reason, and 25\% stated other reasons. The other reasons were because they did not know where to go, they were living in rural area and the hospital was too far, there were no clinics, there were no hospital, and Cambodia was at war when they were pregnant, so they did not have access to healthcare at the time. The mean value for ANC frequencies was 2.7, with a minimum of $O$ and maximum of 20 times. For the women who went for ANC, 55.7\% went to public health centre, $21.4 \%$ went to public hospital, $14.8 \%$ went to other health centre, 3.3\% went to public health post, $1.6 \%$ went to private hospital, 1.6 went to private clinic, and $1.6 \%$ did not know where she went. Other health centers were at home, NGO's clinic, NGO hospital, an organization hospital, or even traditional birth attendant. From all the female respondents who had been pregnant, $36.7 \%$ gave birth at public hospital, $12.7 \%$ at public health clinic, $3.8 \%$ at private hospital, $1.3 \%$ at private clinic, $19 \%$ at home, $22.8 \%$ gave birth at other places, and 1.3\% did not know or remember where. Other places where they gave birth were at home, NGO's clinic, NGO hospital, an organization hospital, a farm, in a village or even at traditional birth attendant. Out of all the women who has ever deliver a baby, 32.9\% stated that they were attended by a doctor, $14.5 \%$ attended by a nurse, 26.3\% attended by midwife, $14.5 \%$ by traditional birth attendant, 7.9\% by Kru Khmer (traditional healer), 3.9\% by other attendants. For question about supplements, $55.1 \%$ of those women stated that they have received supplements after giving birth, 42.3\% said they did not receive any, and $2.6 \%$ said that they did not know or remember.

\section{Child Health and Family Planning}

From the 2012's survey, it was identified that $78.2 \%$ of respondents stated that their children have had BCG vaccination. Tetanus vaccination was also having a good uptake by $78 \%$. $53.4 \%$ of the respondents also claimed that their children have had other kind of necessary vaccinations. The type of other vaccinations were as follow: measleschickenpox-polio-rubella 13.6\%, all of the vaccinations on Childhood Immunization Program 5.7\%, measles 3.4\%, polio $3.4 \%$, measles-Hepatitis B-Japanese Encephalitis $1.1 \%$, do not remember $10.2 \%$, measles-chickenpox $1.1 \%$, measles-hepatitis B-polio 1.1\%, rubellachickenpox $1.1 \%$, rubella-chickenpox-polio $1.1 \%$, unspecified $56.9 \%$. From all the households who reported that they have children living with them, $10.6 \%$ children in the households had some kind of fever in the past 12 months, while 11.8\% had respiratory diseases, and 5.9\% have more than kind of diseases. $48.2 \%$ of households took their children to the public clinic, while $27.7 \%$ took them to the NGO clinic. $17.4 \%$ of households claimed that they had children who died within the first year of their life (1-year mortality) infant mortality). Out of that frequency of infant mortality, 33.3\% was due to an illness, $6.7 \%$ was because of an accident, while the rest $60 \%$ were unspecified.

From the 2013' survey, the frequency of infant mortality was $12.4 \%$. From that frequency, $54.5 \%$ were due to illness, $18.2 \%$ due to accident, while 27.3 were due to unspecified reason or the respondent did not know.

\section{Water, Hygiene and Sanitation}

In 2012, 77.3\% of household' informants claimed that their water source 
were from pipelines, 9.1\% would buy water, $10.2 \%$ got their water from NGO service, and $3.4 \%$ would get their other from more than one source. For the questions of water treatment before consumption, $36.8 \%$ of respondents would boil the water before consumption, while 25\% will add medicine from NGO, 10.5\% used water filter, $7.9 \%$ would add chlorine, $7.9 \%$ used more than one method to treat the water and the rest $11.8 \%$ do not know or did not treat the water. As for toilet facility, 55.3\% stated that they did not have any latrine facility, 18.8\% flushed the waste to the piped sewer system, 12.9\% flushed theirs but had no clue where it ended, $7.1 \%$ used pit latrine, $2.4 \%$ flushed to septic tank, another 2.4 flushed theirs to pit latrine, and 1.2\% flushed it to somewhere else unspecified. Out of those who own tolet facilities, 42.5\% shared use with other households, and $57.5 \%$ of them did not share. For the availability of water to wash hands, 86.9\% households had it and 13.1\% did not, based on intervieer's observation. For the washing-hand facilities, $72.6 \%$ provided soap as cleansing agent, 20.2\% did not provide any cleansing agent, 6\% provided detergent, and 1\% provided other cleansing agent.

From 2013' survey, 31\% of respondents claimed they were using flush to piped sewer system type of toilet, 58.6\% were using rubbish dump sites as toilet, while the rest of $10.4 \%$ used either flush to septic tank or flush to somewhere or hanging toilet to do their business. Washing hand after toilet use was done by $96.6 \%$ of the respondents, while $3.4 \%$ did not or did not specify an answer.

\section{Mental Health}

2012' survey tried to assess mental health status of Prek Torl's residents. One of the indicators is the quantity of time they spend in a day to sleep. For that question, the mean value was 6.98, with minimum of 2 hours and maximum of 12 hours. On the scale 1-10 for satisfaction of current life's condition, the mean value is 4.03. Asked about feeling stressed in the past 3 months, 90.6\% said yes, 8.2\% answered no, while $1.2 \%$ declined to answer. From the respondents who were feeling stressed, 65,4\% said it was from more than one stressor, 16.7\% from financial problems, while the rest 18.9\% split between hunger, disease, living environment, family conflicts, children's growth, and pregnancy. From respondents with multiple stressors, the issues were combination of hunger, disease, living environment, family conflicts, violence, children's growth and development, and unemployment.

Table 1. Comparison between Prek Torl's Household Survey of 2012-2013 and Cambodia's Demographic and Health Survey (DHS) $2010^{8}$

\begin{tabular}{|c|c|c|c|c|c|}
\hline No & Questions & 2012 & 2013 & $\begin{array}{l}2010 \text { DHS } \\
\text { Pnomh Penh }\end{array}$ & $\begin{array}{l}2010 \text { Cambodia } \\
\text { DHS }\end{array}$ \\
\hline 1 & Total Household which was surveyed & 88 & 90 & & 15,667 \\
\hline \multicolumn{6}{|c|}{ Demographic: } \\
\hline 2 & Sex: Female & 81 & 75 & & 18,754 \\
\hline 3 & Sex: Male & 19 & 13 & & 8,239 \\
\hline 4 & Occupation: trash collector (\%) & 47 & 52 & $6,8^{\mathrm{a}}$ & \\
\hline 5 & Education NONE (\%) & 41 & 48,8 & $\begin{array}{l}\mathrm{F}: 8,8 \\
\mathrm{M}: 3,4\end{array}$ & $\begin{array}{l}\text { F: } 15,9 \\
\text { M: } 7,8\end{array}$ \\
\hline
\end{tabular}


6 Education primary 1-6 years (\%)

28

$7 \quad$ Education primary $>7$ Years $(\%)$

Maternal Health and Child Health (\%):

8 No ANC

9 Yes ANC

10 home delivery

11 Birth: delivered by skilled attendant

12 Birth: delivered by TBA/ kru Khmer/ others

\begin{tabular}{llccc}
13 & infant mortality & $17,4^{\mathrm{b}}$ & $12,4^{\mathrm{b}}$ & $45 / 1000^{\mathrm{c}}$ \\
14 & BCG Vaccination & 78,2 & 96,6 & 94,3 \\
\hline Notes: & & \\
a. Percentage for unskilled labor in Pnomh Penh, as the Cambodia's DHS did not have category of trash collector \\
b. Percentage of household who stated that they have had an infant who died before 1rst birthday \\
c. Infant mortality rate as stated by Cambodia's DHS 2010.
\end{tabular}

\section{Correlation between variables}

Table 2. Prek Torl household survey of 2012

\begin{tabular}{lllll}
\hline \multicolumn{1}{c}{ Variables } & $\begin{array}{c}\text { Pearson's } \\
\text { correlation }\end{array}$ & $\begin{array}{c}\text { Sig. } \\
\text { (2-tailed) }\end{array}$ & $\begin{array}{c}\text { Spearman } \\
\text { Correlation }\end{array}$ & $\begin{array}{c}\text { Sig. } \\
\text { (2-tailed) }\end{array}$ \\
\hline $\begin{array}{l}\text { Household income }- \text { infant } \\
\text { mortality }\end{array}$ & $-0,019$ & 0,861 & 0,033 & 0,759 \\
$\begin{array}{l}\text { Education attainment years - } \\
\text { infant mortality }\end{array}$ & 0,091 & 0,416 & 0,128 & 0,253 \\
\hline
\end{tabular}

Table 3. Prek Torl household survey of 2013

\begin{tabular}{lllll}
\hline \multicolumn{1}{c}{ Variables } & \multicolumn{1}{c}{$\begin{array}{c}\text { Pearson's } \\
\text { correlation }\end{array}$} & $\begin{array}{c}\text { Sig. } \\
\text { (2-tailed) }\end{array}$ & $\begin{array}{c}\text { Spearman } \\
\text { Correlation }\end{array}$ & $\begin{array}{c}\text { Sig. } \\
\text { (2-tailed) }\end{array}$ \\
\hline $\begin{array}{l}\text { Education attainment years - } \\
\quad \text { Occupation }\end{array}$ & 0,313 & $0,004^{\mathrm{a}}$ & 0,010 & 0,928 \\
\hline $\begin{array}{l}\text { Household income - ANC visit } \\
\begin{array}{l}\text { Household income - infant } \\
\text { mortality }\end{array}\end{array}$ & 0,080 & 0,592 & $-0,011$ & 0,932 \\
$\begin{array}{l}\text { Education attainment years - } \\
\text { frequency of ANC visits }\end{array}$ & 0,457 & $-0,196$ & 0,066 \\
$\begin{array}{l}\text { Education attainment years - } \\
\text { infant mortality }\end{array}$ & 0,118 & 0,947 & 0,264 & $0,041^{\mathrm{b}}$ \\
$\begin{array}{l}\text { Frequency of ANC visits - } \\
\text { infant mortality }\end{array}$ & 0,021 &,- 102 & 0,359 \\
\hline
\end{tabular}

Notes:

a. Significance at the level of $<0.01$

b. Significance at the level of $<0.05$ 
Table 4. Prek Torl's 2013 survey: Chi Square's test of independence (Crosstabs)

\begin{tabular}{lllllll}
\hline Variables & $\begin{array}{l}\text { Pearson } \\
\text { chi square }\end{array}$ & $\begin{array}{l}\text { df } \\
\text { Asymp. }\end{array}$ & $\begin{array}{l}\text { Likelihood } \\
\text { Sig (2 } \\
\text { sided) }\end{array}$ & $\begin{array}{l}\text { Asymp. Sig } \\
\text { (2 sided) }\end{array}$ & $\begin{array}{l}\text { Fisher exact test } \\
\text { Exact sig. } \\
\text { (2-sided) }\end{array}$ \\
\hline $\begin{array}{l}\text { Literacy (Yes, } \\
\text { No) - Use ANC } \\
\text { (Yes, No) }\end{array}$ & 0,269 & 1 & 0,586 & 0,299 & 0,585 & 0,614 \\
$\begin{array}{l}\text { Use ANC (Yes, } \\
\text { No) - Infant }\end{array}$ & 2,223 & 1 & 0,136 & 2,164 & 0,141 & 0,169 \\
$\begin{array}{l}\text { Death (Yes, No) } \\
\text { Literacy (Yes, } \\
\text { No) - Infant }\end{array}$ & 0,0781 & 1 & 0,781 & 0,079 & 0,779 & 1,000 \\
Death (Yes, No) & & & & & & \\
\hline
\end{tabular}

\section{DISCUSSION}

This household survey has detected some health problems and also some gap between the condition in Prek Torl's community, Pnomh Penh's population, and Cambodia's population. First of all, from the demographic, the level of literacy of Prek Torl's population is much lower than the Pnomh Penh's and Cambodia's. This seems to have a moderate positive correlation with the low level of income, as most of the population worked as trash collector and other unskilled labor. The level of education, which was expressed by the number of years of completed education, also seems to have a weak positive correlation with the number of ANC visits that Prek Torl's women made during pregnancy. This result is consistent with previous studies which found positive correlations between those two variables. Which means that the higher the level of education of women, even men or their spouse, the more likely they will visit ANC services during pregnancy. ${ }^{9}$ Of course, the larger the sample size or size of the population, the stronger the correlation. Previous studies have also mentioned that ANC visit could be used as an important indicator of health outcomes, such as maternal mortality, newborn mortality and infant mortality. ${ }^{9,10,11}$

A large part of the households that were surveyed claimed that it was easy for them to access healthcare when they need it. However, the number of responses with the number of women who visited a healthcare service for ANC is lower than their perception of access to health care. This may means that the respondents did not think that pregnancy is a health issue that requires special health service like ANC. This problem could be explored more in the future, to identify the reason why they did not think that ANC is necessary. ${ }^{12} \mathrm{~A}$ meta analysis of qualitative studies on the topic, done by Finnlayson in 2014, suggested that if the ANC service is not in line with the local socio-cultural context and experiences, also a threat of losing daily income (since making a visit would mean stop working for a day), might lead to the underuse of ANC servic. ${ }^{13}$

The collected data of households that have had infant death may give us an idea of infant mortality's frequency in Prek Torl's community. But it cannot be calculated as infant mortality rate yet, since the data on live birth during the same period, or the past 12 months, was not collected. The calculation of 
correlation using usual predictors (such as level of income, level of education, or even number of ANC visits) have not resulted in weak correlation between the variables, with no statistical significance. The correlation may have been stronger and more statistically significant, if the sample size was larger. However, due to the small size of the whole Prek Torl's population, it may be needed to expand to other villages with similar condition (such as living in or near proximity with a landfill) to obtain a larger sample size. A more detailed questionnaire, exploring into each pregnancies and the outcomes of each pregnancies can also enlarge the sample size, instead of a generalized question for all pregnancy.

\section{LIMITATIONS}

Household surveys like these, with small population have limitations. With the study focused only in Prek Torl, which population is around 200 households, simple random sampling was not suitable and convenience sampling was used. The survey was done in limited time as well, thus it did not cover all of the households. There were no identified local registers or local administrative data on the households in Prek Torl's village, made it difficult for researchers to confirm the CUHK's data with local village data. To be compared with Cambodia's DHS 2010 may not be quite appropriate, since the DHS was done with large sample and with more varied categories or stratification of populations, while Prek Torl's have much less size of population and less variety within the population. The questions on infant mortality, antenatal care visits, and any other maternal and child health indicators were generalized for all pregnancies and all children in the household, instead of seeking into each pregnancy and into each child health status. If the questions and data collections were more detailed on individual cases of pregnancy, the outcomes and individual child, the sample size of cases might have been larger and the statistical assumption might have been more accurate or significant.

\section{CONCLUSION}

The findings of this study suggested that low level of education and income is connected with the uptake of antenatal service. The perception of access to health care is not in line with the uptake of antenatal service. More qualitative studies might be needed to explore the reasonforthat issue. Further studies, with larger sample size on more communities with similar characters, may shed more light on the reason of why women did not use antenatal service, and in time may help in designing new interventions for delivering more suitable maternal and child health care for the particular population.

\section{RECOMMENDATION}

Interventional programs to increase the uptake of antenatal service are necessary in this community. Further studies on other communities with similar conditions may reveal more health needs, especially regarding maternal and children health.

\section{REFERENCES}

1. Vrijheid,M.Healtheffects of residence near hazardous waste landfill sites: A review of epidemiologic literature. Environ. Health Perspect. 2000, 108, 101-112.

2. Porta D, Milani S, Lazzarino AI, Perucci CA, Forastiere F: Systematic review of epidemiological studies on health effects associated with management of solid waste. Environ Health 2009, 8:60. 
3. World Bank. Accessed in February 2014. Available at: http://www. worldbank.org/en/country/cambodia/overview.

4. WHO and Ministry of Health - Cambodia. 2012. Health Service Delivery Profile. Available at: http://www. wpro.who.int/health_services/service_delivery_profile_cambodia.pdf

5. Zina Jarrah. 2008. Strengthening Cambodia's Health System through Contracting of Health Centers. Boston University School of Public Health. Available at: http://www. bu.edu / ihblast/files / 2012/02/ CulminatingExperience_ZJARRAH1.pdf.

6. http://www.unicef.org/eapro/ Health_Service_Access_Among_ Poor_Communities_Phnom_Penh_\%28Low.pdf.

7. https://www.cambodianchildrensfund.org.

8. Directorate General for Health (DGH) of the Ministry of Health and the National Institute of Statistics of the Ministry of Planning. Cambodia 2010 Demographic and Health Survey.
9. Simkhada et al. Factors Affecting the utilization of antenatal care in developing countries: systematic review of the literature. JAN (2007).

10. Bhatia JC, Clelan J. Determinants of maternal care in a region of South India. Health Transition Centre (1995), National Centre for Epidemiology and Population Health, the Australian National University. Available at: http://hdl.handle. net/1885/41182.

11. Nuraini E, Parker E. Improving Knowledge of Antenatal Care (ANC) among Pregnant Women: A Field Trial in Central Java, Indonesia. Asia Pac J Public Health January 2005 vol. 17 no. 1 3-8.

12. Gabrysch, Campbell. Still too far to walk: Literature review of the determinants of delivery service use. BMC Pregnancy and Childbirth 2009, 9:34.

13. Finlayson K, Downe S (2013) Why Do Women Not Use Antenatal Services in Low- and Middle-Income Countries? A Meta-Synthesis of QualitativeStudies. PLoS Med 10(1): e1001373. doi:10.1371/journal. pmed.1001373. 